\title{
The Relationship Between English Reading Proficiency and Academic Achievement of First-Year Science and Mathematics Students in a Multilingual Context
}

\author{
Lieke Stoffelsma $^{1,2} \cdot$ Wilbert Spooren ${ }^{3}$
}

Received: 29 April 2017 / Accepted: 27 May 2018/Published online: 18 June 2018

(C) The Author(s) 2018

\begin{abstract}
This study reports on a conceptual model that provides insight into the relationship between English reading proficiency and academic performance of firstyear science and mathematics university students in Ghana, and an empirical test of that model. Longitudinal data were acquired from a sample of 133 students. Using three different mediation analyses, the study demonstrated significant medium-sized effects of English reading proficiency on students' grade point average (GPA) by the end of year 1 and a small but significant indirect relationship between reading proficiency and the final GPA scores by the end of year 4, mediated by the GPA scores after year 1 . These findings show that the academic English reading proficiency of students in a non-western multilingual academic context is important for their academic achievement. It also found that academic results obtained by students in their first-year at University were a sound predictor for success at the end of their studies. Results from this study confirm the need for universities in multilingual settings to invest in L2 students' English reading proficiency at the start of their academic programs. Instructional recommendations are made, along with suggestions for further study.
\end{abstract}

Keywords English reading proficiency · English second language (ESL) ·

Multilingualism $\cdot$ Science- and mathematics education $\cdot$ Scientific literacy

Lieke Stoffelsma

1.stoffelsma@1et.ru.nl

Wilbert Spooren

w.spooren@let.ru.nl; http://wilbertspooren.ruhosting.nl

1 Department of Linguistics \& Modern Languages, University of South Africa (UNISA), Pretoria, South Africa

2 Centre for Language studies, Faculty of Arts, Radboud University Nijmegen, P.O. Box 9103, 6500 HD Nijmegen, The Netherlands

3 Centre for Language studies, Faculty of Arts, Radboud University Nijmegen, Room E6.29 /

E13.04, P.O. Box 9103, 6500 HD Nijmegen, The Netherlands 


\section{Introduction}

Language is an integral part of science: it "shapes science ideas and understanding, and the non-language features of science shape scientific discourse" (Locke, 1992, as cited in Hand et al., 2003, p. 608). The recognition that language interacts with learning in science and mathematics education has led to an increased demand for content-area literacy instruction (cf. Carnegie Council on Advancing Adolescent Literacy, 2010; Fang et al., 2008; Hand et al., 2003; Norris \& Phillips, 2003). The relatively recent research focus on "disciplinary literacy" (Carnegie Council on Advancing Adolescent Literacy, 2010, p. 22) has produced strong evidence of a positive relationship between reading proficiency and academic performance in science and mathematics education. Disciplinary literacy, or content-area specific literacy, consists of literacy skills and knowledge that support students' understanding of concepts related to a particular field of study, such as science and mathematics. Evidence for this support was found at primary level (Vilenius-Tuohimaa, Aunola, \& Nurmi, 2008; Walker, Zhang, \& Surber, 2008), at secondary level (Korpershoek, Kuyper, \& Van der Werf, 2015; Ní Ríordáin \& O'Donoghue, 2009) and at tertiary level (Pretorius, 2002).

Special attention to disciplinary literacy in science and mathematics education is important for a number of reasons. Science texts are often challenging to students and require extra efforts to process. They are informative by nature and usually present dense and abstract concepts, use unfamiliar terminology and language that students are not likely to encounter in their daily language use (Palinscar, 2013). The expository and technical nature of science texts places high demands on students' language skills. The latter include knowing specialized vocabulary; interpreting scientific symbols and diagrams; recognizing and understanding organizational patterns common to science texts; inferring main ideas, using inductive and deductive reasoning skills; and recognizing cause-and-effect relationships (Barton \& Jordan, 2001). Profound mastery of language skills and reading proficiency are therefore indispensable for students who are studying science and mathematics, whether at primary, secondary or at tertiary level.

This is even more so for students in multilingual or bilingual contexts, who are not taught in their mother tongue but in a second language (L2). Fang (2006) argues that the specific linguistic features that make science texts more dense and abstract can cause reading comprehension problems especially for English L2 learners. Due to a global increasing migration and movement of people, bilingual and multilingual contexts are growing. It is estimated that half of the world population uses more than one language or dialect in their everyday life (Ansaldo, Marcottea, Schererc, \& Raboyeaua, 2008). This expansion of multilingualism justifies more attention for the literacy practices of L2 learners in science and mathematics education (cf. Barwell, Barton, \& Setati, 2007; Rhodes \& Feder, 2014).

Most research into L2 literacy practices in science and mathematics education comes from the more affluent western world. Ironically, L2 research into the rich multilingual settings of Africa, where it is most needed, is scarce (Paran \& Williams, 2007; Pretorius \& Mampuru, 2007), with the exception of South Africa (cf. Boughey, 2005; Dowse \& Howie, 2013; Inglis, Kirkwood, Downs, \& Parkinson, 2007; Pretorius, 2000, 2002, 2005, 2006; Pretorius \& Bohlmann, 2003; Prins \& Ulijn, 1998; Van Wyk \& Greyling, 
2008). The current paper is inspired by the paucity of research in the rest of Africa regarding the role of language in science and mathematics education at tertiary level. It is an attempt to fill this research gap, and in particular to better understand the role of students' English reading proficiency on academic achievement in a non-western, multilingual educational setting. It reports on a conceptual model that provides insight into the relationship between English reading proficiency and academic performance of first-year science and mathematics university students in Ghana, and an empirical test of that model.

\section{Context}

One of the main goals of education for the new independent Ghana, as outlined in 1957 by Ghana's first president, Dr. Kwame Nkrumah, was to produce a scientifically literate population as an answer to poverty and to increase economic productivity (Akyeampong, 2010). Since the 1950s, Ghana has made a lot of economic progress. The World Bank Global Economic Prospects positioned Ghana as the fastest growing economy of Sub Sahara Africa in 2011. As a result, Ghana moved from low-income to lower middle-income status in 2011 (World Bank, 2011). Ghana's positive economic developments are reflected in a reduction of national poverty levels over the past two decades. Following Cooke, Hague, and McKay (2016), Ghana's national level of poverty was reduced by more than half, from 56.5 to $24.2 \%$, between 1992 and 2013. Although this is an impressive achievement, it also indicates that almost a quarter of the population is still living below the poverty line. In addition, the authors caution that the annual rate of reduction of the poverty level is slowing down and that the gap between rural and urban poverty has doubled since the 1990s.

With regard to Ghana's educational development, a lot of progress has been made since independence, but challenges remain. There are concerns about equitable access, lack of enrolment at primary level, low quality of education, regional disparities, teachers' work and living conditions, and lack of investments in science and technology related academic programs (Akyeampong, 2010).

A particular field of concern is the quality of science and mathematics education. Ghana's performance of eighth grade students in science and mathematics international benchmarks remains among the lowest in Africa and the world (Mereku \& Anumel, 2011). Ghana participated in the Trends in International Mathematics and Science Study (TIMSS) in 2003, 2007 and 2011. ${ }^{1}$ TIMMS is a series of international assessments that was initiated in 1995, with the aim "to improve the teaching of mathematics and science by providing data about students' achievement in relation to different types of curricula, instructional practices, and school environments" (Mullis, Martin, Gonzalez, \& Chrostowski, 2004, p. 15). While Ghana's participation in TIMMS mathematics shows improved results over the years (i.e., from a scale score of 276 in the year 2003, to 309 in 2007 and 331 in 2011), Ghana was ranked at the 47th position on the overall mathematics achievement out of the 48 participating countries in 2007. Ghana's achievement in TIMMS science has also shown some improvement over the years (from an average score of 255 in the year 2003, to 306 in 2011), but it

\footnotetext{
${ }^{1}$ Ghana did not participate in TIMSS 2016 due to lack of funding.
} 
has been consistently poor (Buabeng, Acheaw Owusu, \& Danso Ntow, 2014). In 2011, there was no significant improvement compared to 2007, and Ghana's achievement was the lowest of all 42 participating countries, among which were five African countries (Martin, Foy, \& Stanco, 2012).

Although it could be argued that TIMSS results are culturally biased against African countries, there are a few arguments that support the use of these findings. Firstly, the development of the TIMMS assessment was a two-and-a-half-year process in which mathematics and science educators and development specialists from all over the world participated. The instruments followed a thorough translation process during which texts were adapted to make unfamiliar contextual terms culturally appropriate (e.g., inch versus centimeter; liters versus quarts; decimal point versus decimal comma) (Martin, Mullis, \& Chrostowski, 2003, p. 99). Also, there are no real alternatives in the form of culturally appropriate tests that compare mathematics and science achievement in the region, as is the case for SACMEQ countries. ${ }^{2}$ Moreover, the kind of reading that the Ghanaian students have to perform is often based on European and North-American textbooks, which means they will be confronted with the same type of science literacy as their peers in other countries.

A complicating factor in improving the quality of science and mathematics education in Ghana is the lack of interest of students to enroll in science and technology programmes. In 2010, the ratio of enrolment in state universities for humanities and science and technology based programs was highly uneven: about 65:35. In order to increase enrolment for these subjects, Akyeampong (2010) calls for an improvement of quantity and quality of science and mathematics teachers at secondary schools. This will be a challenging task, since about $19 \%$ of all science teachers and $13 \%$ of all mathematics teachers at secondary schools are not professionally qualified (De Feiter, 2006). The Ministry of Education (2016) recognizes that, in spite of an increase of the number of students who qualify for tertiary education between 2007 and 2012, performance in mathematics and science at secondary schools in Ghana has been poor.

The causes of the problem are very diverse, but many have a linguistic component. Research shows that highly educated parents and homes with extensive literacy resources, such as books, contribute to students' school results in science and mathematics (Mullis et al., 2004). On the other hand, low school performance in science and mathematics is influenced by poor teaching methodologies, inadequate teaching and learning materials, the lack of understanding of questions, poor language and communication skills, poor techniques of answering questions and the lack of in-depth treatment of topics (Ministry of Education Ghana, 2016). Lack of communication skills training in the mathematics curriculum was also identified by teachers as contributing to the poor performance in TIMMS 2007 (Mereku \& Anumel, 2011). Although these studies point towards language-related factors as possible causes of students' poor performance in science and mathematics education in Ghana, there is no evidence for a direct relationship between students' English reading proficiency and their academic performance. It is however clear that the English reading proficiency of

\footnotetext{
2 The Southern and Eastern Africa Consortium for Monitoring Educational Quality (SACMEQ) has published a broad range of comparative educational studies, including students' achievement in reading and mathematics in 16 countries in Southern and Eastern Africa.
} 
primary and secondary school students in Ghana is low (Leherr, 2009; Ministry of Education Ghana, 2008, 2010), and has been low already for many years:

Time and again, the English language ability of pupils as measured by national examinations is proving to be the limiting factor in promoting effective comprehension of knowledge and skills. This has led to a situation where many, including parents, especially in the rural areas, voice concern that unless that problem is seriously addressed meaningful learning of subjects cannot take place (Ampiah, Akyeampong, \& Leliveld, 2002, p. 24)

Also at tertiary level, the English reading proficiency of students in Ghana is in need of improvement. A recent study amongst 496 first-year Bachelor of Education (B.Ed.) students in Ghana showed that $52 \%$ of the students had a reading ability that was not sufficiently adequate for reading academic expository texts (Stoffelsma \& De Jong, 2015).

\section{Theoretical Underpinning}

The conceptual model used in this paper assumes a direct relationship between L2 students' academic English reading proficiency and their academic achievement in science and mathematics education at B.Ed. level. The evidence on which this model is based, is presented in the following paragraphs. The B.Ed. level was purposefully chosen because these B.Ed. students are trained to become the future science and mathematics teachers of Ghana. It is therefore expected that their reading skills will influence the quality of their teaching, and have an effect on improving the quality of education in the country.

Although the concept of scientific literacy is generally claimed to be the desired outcome of science education, it has been defined in many different ways since it was introduced in the late 1950s (De Boer, 2000). One commonality of the concept is that it "has usually implied a broad and functional understanding of science for general education purposes and not preparation for specific scientific and technical careers" (p. 594). The definition of scientific literacy by the Organisation for EconomicCooperation and Development (OECD, 2013) reads as follows: "Scientific Literacy is the ability to engage with science-related issues, and with the ideas of science, as a reflective citizen" (p.7). Following this definition, a scientifically literate person has the competencies to explain phenomena scientifically, evaluate and design scientific enquiry and interpret data and evidence scientifically.

Norris and Phillips (2003) propose a dual approach to scientific literacy. They distinguish between the fundamental and derived sense of scientific literacy. The fundamental sense of literacy means being knowledgeable, learned, and educated in science. The derived sense means the ability to read and write and to understand the communication systems of science. Norris and Phillips argue that the fundamental sense of literacy is central to scientific literacy: "Nobody can acquire a sophisticated level of scientific knowledge without being literate in the fundamental sense, and science itself could never exist without individuals literate in this way" (p. 236). The current conceptual model follows the dual approach proposed by Norris and Phillips, and assumes that the derived sense of scientific literacy, i.e., reading and writing, is a necessary condition for the academic achievement of science and mathematics students. 
Subsequently, those students who sufficiently master scientific reading and writing skills will eventually become scientifically literate in the fundamental sense.

A growing body of research in western and non-western contexts supports the idea that reading skills play a decisive role in academic achievement, including in domains typically associated with logical-deductive skills, such as science and mathematics. Fang and Wei (2010) show that integrating reading instruction in the science curriculum at secondary level has a significant positive impact on students' science literacy. Mol and Bus (2011) found proof that frequent readers are more successful students, and that print exposure explains $34 \%$ of the variance in oral language skills for college and university students. Pretorius (2000) argues that the better students are at making inferences while they read (e.g., linking different ideas in a text), the better they perform academically. Finally, Lyengar (2007) presents evidence that the habit of daily reading correlates positively with better reading skills and higher academic achievement.

How different is learning science or mathematics if English is not your mother tongue? In general, L2 language learners lag behind their first language peers in reading literacy skills (Droop \& Verhoeven, 2003; Mullis, Martin, Kennedy, \& Foy, 2007). This is caused by a number of factors.

Reading is considered to be an interactive process during which information processing is established through interaction between components at a lower (bottom-up) and higher level (top-down). The bottom-up skills refer to word level identification skills needed for decoding, whereas the top-down skills refer to cognitive processes and world knowledge that we need for comprehension (Birch, 2015; Stanovich, 2000). Lems and Miller (2017) argue that the bottom-up skills form the greatest obstacle for L2 learners of English, not only because these skills are language-specific and need to be learned for each language separately, but also because English word decoding is highly complex. This idea is supported by Grabe (2009) who argues that L1 readers are likely to have developed implicit linguistic knowledge of syntax, morphology and phonology by the age of six, whereas their L2 peers have not.

In addition to mastering decoding skills, vocabulary knowledge plays a key role in L1-L2 reading differences. Research has shown that vocabulary correlates strongly with reading comprehension and is an important prerequisite for reading skills (Helman \& Burns, 2008; Stæhr, 2008). Whereas L1 readers are likely to know between 3000 and 8000 words orally before they start to read, it will take L2 learners at least several years to develop such knowledge and abilities (Grabe, 2009). At the same time, their L1 peers will continue to add to their vocabulary, making it more difficult to close the gap (Lems \& Miller, 2017). Finally, an important difference between L1 and L2 readers is their exposure to print. It is generally assumed that L2 readers have far less exposure to reading materials in the L2 than their L1 counterparts. This has to do with the fact that most of the L2 readers only encounter L2 words in their school setting, whereas L1 readers are likely to come across more L1 words in their daily routines (e.g., books, newspapers, magazines, public information boards, etc.) (Grabe, 2009).

Nevertheless, there are some important benefits for L2 readers. L2 readers have higher levels of metalinguistic awareness (Grabe, 2009). Bilingualism is unlikely to have a negative effect on mathematic proficiency, and even may result in cognitive advantages (Moskovich, 2007). On the basis of the presented research, we presume that the students' academic performance will be related to their English reading proficiency. To investigate that hypothesis, we made use of longitudinal data collected over the 
course of the 4 years: English reading assessment in year 1 and grade point average (GPA) scores in year 1 and 4.

Our expectations about these data can be modeled in a mediation model (Fig. 1):

Due to the exploratory nature of the current study, and the unknown level of students' English reading proficiency that participated in this study, the reading assessment was based on items from two internationally recognized reading comprehension tests, measuring distinct reading levels: the PISA test and the Pearson Test of English Academic (PTE Academic reading). The PISA test measures in how far 15-year-old students have acquired the knowledge and skills that are essential for full participation in society either by joining the workforce or by continuing further studies (OECD, 2002). The test is one of the major international reading tests at secondary school level with proven reliability and validity. The PTE targets English L2 students of at least 17 years old, and measures whether the English reading proficiency they have acquired is at a level that would allow them to follow university level courses and participate in academic life where English is the language of instruction and communication.

It was expected that the grades after one year of academic education acts as a mediator in predicting the relationship between proficiency in English and academic performance at the end of the program. Based on the described evidence, the following hypothesis was formulated for the current study:

- $\mathrm{H} 1$ : there is a serial mediation relationship between the English reading proficiency of first-year science and mathematics students in Ghana and their GPA after year 4, that is mediated through the students' GPA after year 1 .

\section{Methods and Materials}

\section{Sample and Procedure}

Convenience samples of 171 B.Ed. Science and Mathematics students from a teacher training university in Ghana were taken. The sample was part of a lager sample of 496 firstyear students, which contained 34.5\% B.Ed. Mathematics students, and 20.2\% B.Ed. Science students. Details of the larger study are presented in Stoffelsma and De Jong (2015).

At the start of the first semester of their program, the PISA and PTA tests (described below) were administered to all students, using a paper-based format, during a test session after class hours. There was a strict time limit set of 60 minutes to complete the test. For this group, GPA scores were collected at the end of academic year 1 and of year 4. In total, GPA scores from 146 students were available. By the end of year 1, a

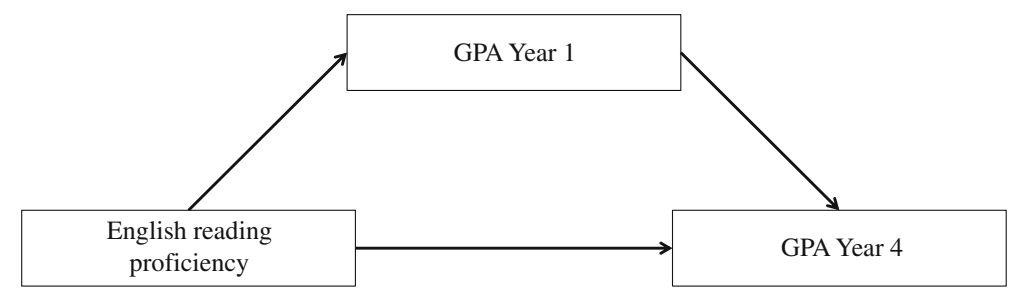

Fig. 1 Conceptual model English reading proficiency and GPA year 1 and 4 
Table 1 Sample characteristics: academic program, age, gender and home language

\begin{tabular}{lcllll}
\hline Programme & N $(\%)$ & Average age & Male (\%) & Female (\%) & $\begin{array}{l}\text { Number of languages } \\
\text { spoken at home }\end{array}$ \\
\hline BEd Mathematics & $78(58.6)$ & 23.0 & 91 & 9 & 16 \\
BEd Science: & $55(41.4)$ & 24.8 & 79 & 21 & 13 \\
BEd Physics & $7(5.3)$ & 23.6 & 100 & 0 & 3 \\
BEd Int. Science & $14(10.5)$ & 25.7 & 71 & 29 & 7 \\
BEd Biology & $19(14.3)$ & 24.3 & 63 & 37 & 8 \\
BEd Chemistry & $15(11.3)$ & 25.2 & 93 & 7 & 6 \\
Total & $133(100)$ & 23.7 & 100 & 100 & 20 \\
\hline
\end{tabular}

total of 13 students (3 B.Ed. Mathematics and 10 B.Ed. Science) had dropped out of the program. These were not included in the analyses. Therefore, the final sample amounted to a total of 133 students.

\section{English Reading Proficiency}

To measure the English reading proficiency of the students, a total of 54 reading test items were selected from two internationally recognized reading comprehension tests: 26 from the PISA 2000 Reading test (OECD, 2006) and 28 items from the Pearson Test of English Academic (PTE Academic). The PISA items measured the following five aspects of understanding a text: (1) forming a broad general understanding; (2) retrieving information; (3) developing an interpretation; (4) reflecting on the content of a text; and (5) reflecting on the form of a text (OECD, 2006). The selected PTA items measured academic reading proficiency at an average B1 level. ${ }^{3}$ Further details of the test are reported in Stoffelsma and De Jong (2015).

The English reading proficiency of the sample in our study is reported in percentage correct scores at three levels: (1) the combined reading test (results of all PISA and PTA items); (2) the PISA test results and (3) the PTA test results. For practical purposes, the terms "PISA reading test" and "PTA reading test" are used in the reporting to refer to the 26 and 28 selected items, although the PISA and PTA items used in this study did not encompass the full original tests.

\section{Demographics}

The students who participated in the study were asked for their age, gender, and choice of academic program and the language spoken in the home environment. Students were

\footnotetext{
3 The Common European Framework of Languages (CEFR) specifies the B1 level (independent user) as follows: "Can understand the main points of clear standard input on familiar matters regularly encountered in work, school, leisure, etc. Can deal with most situations likely to arise whilst travelling in an area where the language is spoken. Can produce simple connected text on topics which are familiar or of personal interest. Can describe experiences and events, dreams, hopes and ambitions and briefly give reasons and explanations for opinions and plans" (Council of Europe, 2001, p. 24).
} 
Table 2 English reading proficiency test scores (Combined, PISA and PTA); GPA year 1 and GPA year 4 per study program (means in percentages and SE)

\begin{tabular}{llllll}
\hline Study program (N) & $\begin{array}{l}\text { Combined } \\
\text { reading test }\end{array}$ & $\begin{array}{l}\text { PISA } \\
\text { reading test }\end{array}$ & $\begin{array}{l}\text { PTA } \\
\text { reading test }\end{array}$ & GPA year 1 & GPA year 4 \\
\hline BEd Mathematics (78) & $61.5(1.7)$ & $70.0(2.3)$ & $53.5(2.0)$ & $2.7(0.0)$ & $2.8(0.0)$ \\
BEd Science (57) & $61.9(2.3)$ & $72.4(2.7)$ & $52.0(3.0)$ & $2.5(0.1)$ & $2.6(0.1)$ \\
BEd Physics (7) & $55.4(10.7)$ & $66.9(9.8)$ & $43.5(12.4)$ & $2.4(0.3)$ & $2.3(0.2)$ \\
BEd Int. Science (14) & $57.0(3.3)$ & $64.0(6.2)$ & $51.5(4.6)$ & $2.6(0.1)$ & $2.7(0.1)$ \\
BEd Biology (19) & $66.2(3.3)$ & $78.5(4.1)$ & $54.8(4.6)$ & $2.4(0.1)$ & $2.6(0.1)$ \\
BEd Chemistry (15) & $63.1(4.7)$ & $74.8(4.4)$ & $51.5(6.2)$ & $2.5(0.2)$ & $2.7(0.1)$ \\
All programs (133) & $61.6(1.4)$ & $70.9(1.8)$ & $52.7(1.7)$ & $2.6(0.0)$ & $2.7(0.0)$ \\
\hline
\end{tabular}

Note. Reading tests are presented as percentage correct scores. GPAs are presented as scores on a scale from 1 to 4 . Standard error is presented between parentheses

asked to include their student numbers in order to follow-up on students' academic achievement (GPA) after year 1 and year 4 .

Students in the B.Ed. programs of the study were predominantly male. Their age ranged from 18 to 42 , with the highest average for the Integrated Science students (25.7 years old). Ghana's multilingual nature is clearly reflected within the student population, with as many as 20 different languages spoken by the students. Out of all the students, $10.3 \%$ reported speaking English in the home environment. This does not imply, however, that English is their mother tongue. In a similar study, targeting the same population, only $0.3 \%$ of the student population reported English as their mother tongue (Stoffelsma \& Spooren, 2013). In line with these findings, the students in the current study are considered to be L2 learners.

The demographics are summarized in Table 1.

\section{Data Analysis}

The reading test items were analyzed using the Rasch model ${ }^{4}$ and average results per student were calculated. Academic records of 133 students who participated in the reading test were linked to their language test results. Simple mediation analysis was used to investigate the assumed relations between academic English reading proficiency and academic achievement (GPA year 1 and year 4), based on the Process procedure model 4 (Hayes, 2013). Three separate analyses were carried out: one with the English reading proficiency results of both PISA and PTA items (combined reading test), one with the PISA test items only, and one with the PTA test items only. Following Hayes (2013), mediation analysis was used to investigate the direct and indirect ways through which an antecedent variable $\mathrm{X}$ (in this case reading proficiency) transmits its effect on a consequent variable Y (in this case GPA4) via a mediator (in this case GPA1).

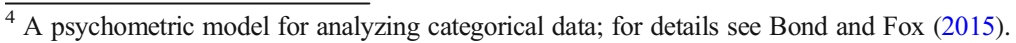


Table 3 Summary of the mediation analysis English reading proficiency (combined test)

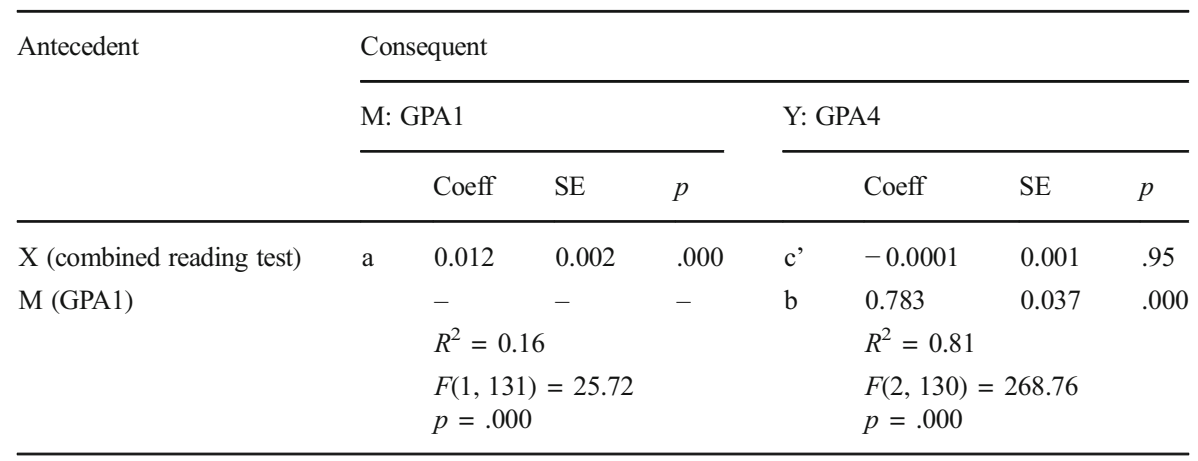

\section{Results}

Results of the language test show that B.Ed. Chemistry students had the highest average score on the combined English reading test (63.1\% correct), whereas the B.Ed. physics students obtained the lowest score on the combined English reading test (55.4\% correct). For the detailed results of the language test and their relation with international benchmarks, the reader is referred to Stoffelsma and De Jong (2015).

There was a statistically significant difference between the scores on the PISA test $(\mathrm{M}=70.9, \mathrm{SE}=1.78)$ and the PTA scores $(\mathrm{M}=52.7, \mathrm{SE}=1.71)$ scores; $t(132)=$ $8.43, p<0.001$. The academic results show that students have a statistically significant higher average for their GPA4 results $(\mathrm{M}=2.75, \mathrm{SE}=0.04)$, compared to their GPA1 results $(\mathrm{M}=2.63, \mathrm{SE}=0.04) ; t(132)=-6.47, p$ $<.001)$. For details see Table 2.

The conceptual model assumes a serial mediation relationship between students' English language proficiency, GPA year 1 and GPA year 4: a high score on the different language tests will have a positive impact on the GPA year 1, which in turn will lead to a higher GPA in year 4. To test this conceptual model, the following test results were used: the combined reading test (PISA and PTA); the PISA reading test; the PTA reading test; GPA year 1 (GPA1) and GPA year 4 (GPA4).

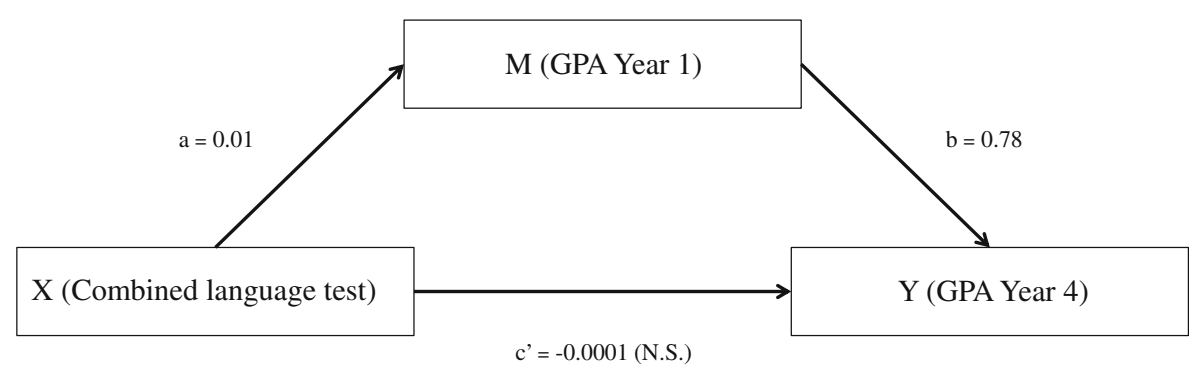

Fig. 2 Mediation analysis combined reading test, GPA4 with GPA1 as mediator 
Table 4 Summary of the mediation analysis English reading proficiency (PISA reading test)

\begin{tabular}{|c|c|c|c|c|c|c|c|c|}
\hline \multirow[t]{3}{*}{ Antecedent } & \multicolumn{8}{|c|}{ Consequent } \\
\hline & \multicolumn{4}{|c|}{ M: GPA1 } & \multicolumn{4}{|c|}{ Y: GPA4 } \\
\hline & & Coeff & SE & $p$ & & Coeff & SE & $p$ \\
\hline $\mathrm{X}$ (PISA reading test) & a & 0.008 & 0.002 & .000 & $c^{\prime}$ & -0.0001 & 0.001 & .88 \\
\hline \multirow[t]{3}{*}{ M (GPA1) } & & - & - & - & $\mathrm{b}$ & 0.784 & 0.036 & .000 \\
\hline & \multicolumn{4}{|c|}{$R^{2}=0.12$} & & \multicolumn{3}{|c|}{$R^{2}=0.81$} \\
\hline & \multicolumn{4}{|c|}{$\begin{array}{l}F(1,131)=17.61 \\
p=.000\end{array}$} & & \multicolumn{2}{|c|}{$\begin{array}{l}F(2,130)=268.81 \\
p=.000\end{array}$} & \\
\hline
\end{tabular}

\section{Combined Reading Test}

Mediation analysis results of the combined reading proficiency test results on GPA1 and GPA4 are presented in Table 3 and Fig. 2. There is a statistically significant direct effect of the combined English reading test results on the academic achievement after 1 year $($ Coeff $=0.012, p<.001)$. There is no statistically significant direct effect of the combined reading test results on academic achievement after 4 years (Coeff $=-0.0001, p=0.95$ ). There is a strong effect of GPA year 1 results on GPA year 4 results (Coeff $=0.783, p<.001$ ). There is also an indirect effect of the combined reading test results on academic achievement after 4 years. The coefficient for the indirect effect of the reading test $(\mathrm{X})$ on the GPA year $4(\mathrm{Y})$ is $0.01(p<.001)$.

\section{PISA Reading Test}

Mediation analysis results of the PISA English reading proficiency test on GPA1 and GPA4 are presented in Table 4 and Fig. 3. There is a statistically significant direct effect of the PISA reading test results on the academic achievement after 1 year $($ Coeff $=0.008, p<.001)$. There is no statistically significant direct effect of the PISA reading test results on academic

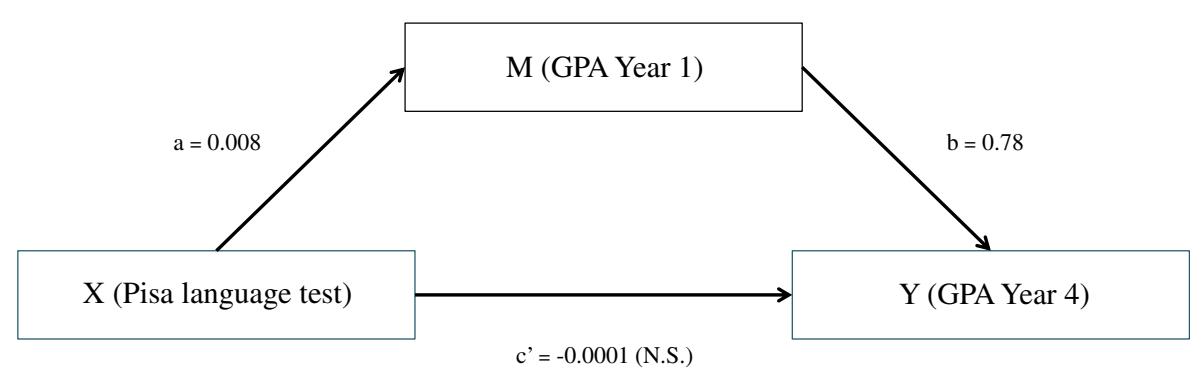

Fig. 3 Mediation analysis PISA reading test, GPA4 with GPA1 as mediator 
Table 5 Summary of the mediation analysis English reading proficiency (PTA reading test)

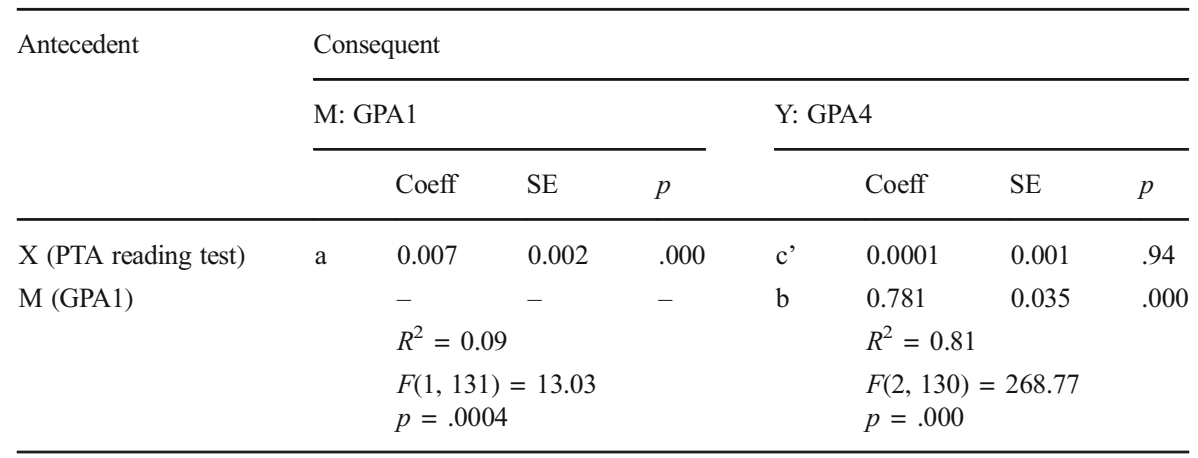

achievement after 4 years (Coeff $=-0.0001, p=0.88)$. There is a strong effect of GPA year 2 results on GPA year 4 results (Coeff $=0.784, p<.001)$. There is also an indirect effect of the PISA reading test results on academic achievement after 4 years. The coefficient for the indirect effect of the PISA reading test $(\mathrm{X})$ on the GPA year $4(\mathrm{Y})$ is $0.01(p<.001)$.

\section{PTA Reading Test}

Mediation analysis results of the PTA English reading proficiency test on GPA1 and GPA4 are presented in Table 5 and Fig. 4. There is a statistically significant direct effect of the PTA reading test results on the academic achievement after 1 year $($ Coeff $=0.007, p<.001)$. There is no statistically significant direct effect of the PTA reading test results on academic achievement after 4 years $($ Coeff $=0.0001, p=0.94)$. There is a strong effect of GPA year 2 results on GPA year 4 results (Coeff $=0.781, p<.001)$.There is also an indirect effect of the PTA reading test results on academic achievement after 4 years. The coefficient of the indirect effect of the PTA reading test $(\mathrm{X})$ on the GPA year $4(\mathrm{Y})$ is $0.005(p<.001)$.

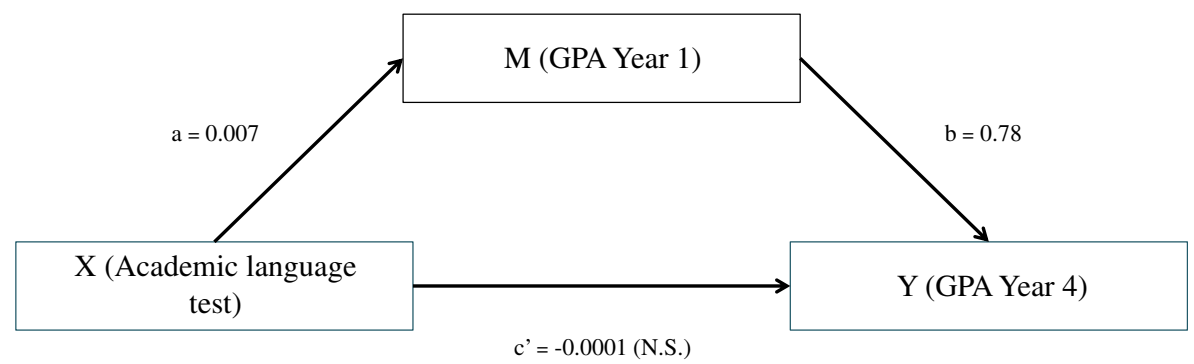

Fig. 4 Mediation analysis PTA reading test, GPA4 with GPA1 as mediator 


\section{Conclusion and Discussion}

This study investigated the role of English reading proficiency on the academic achievement in a sample of B.Ed. Science and Mathematics students of whom longitudinal data were acquired. Using three different mediation analyses, the study demonstrated statistically significant medium-sized effects of all three predictors on GPA year 1: the combined reading test; the PISA reading test and the PTA reading test. A small but statistically significant indirect relationship between reading proficiency of all three predictors was found on the final GPA scores (GPA4), mediated by the GPA scores after year 1 (GPA1). These findings show that students' academic English reading proficiency is important for their academic achievement in a multilingual academic context. Combining two internationally recognized reading comprehension tests allowed for a broad measurement of students' reading skills. Not only were students tested on reading skills needed by $15-$ year-olds for full participation in society, but they were also tested on their preparedness for processing texts in a university setting. The fact that both measurements (PISA and PTA) had a substantial effect on students' academic achievement in year 1 indicates that first-year B.Ed. students need to possess a variety of reading skills to cope with their studies. Both the more general reading skills as measured by the somewhat easier PISA test, as well as the academic reading skills as measured by the more difficult PTA test are important for academic success.

A strong effect was found between students' academic achievement after their first year of studies (GPA1) and their final year (GPA4) $\left(R^{2}>.80\right)$. This is an indication that academic results obtained by students in their first year at University are a sound predictor for success at the end of their studies. The data also show that students grow during their studies and obtain statistically significantly higher grades in year 4 than in year 1 of their programs. This might be explained by the fact that students who are new in the system still have to adjust themselves to the academic discourse and teaching methods. Later on in their studies, students are likely to be more accustomed to university and have grown into studying habits.

The added value of the current research is threefold. Our research broadens the focus of $\mathrm{L} 2$ reading research in science and mathematics education in an African multilingual context. As argued in the introduction, fundamental research into reading in developing countries is scarce. Furthermore, our study added substantially to our understanding of the relation between L2 students' English reading proficiency and their science and mathematics achievement at tertiary level. The study corroborates previous findings of the role of language in the science and mathematics curriculum (presented in the introduction), based on data from a West-African context. Finally, by taking a longitudinal approach, it shows that even after 4 years of study, there is an indirect mediation relation between reading proficiency and academic achievement.

These findings have important instructional implications. Our data confirm the need for universities to invest in L2 students' reading proficiency at the start of their academic programmes. Some universities in Ghana have introduced a compulsory Communicative Skills (CS) program, in which students are trained in language and communication skills. However, the generic character of CS and its low effectiveness have led some scholars to propose giving more attention to discipline-specific language skills (Afful, 2007; Odamtten, Denkabe, \& Tsikata, 2015). This attention should go beyond building 
vocabulary and mastery of word-reading skills, because this is not a guarantee that students can comprehend science texts (Carnegie Council on Advancing Adolescent Literacy, 2010). Specific attention to processing science text is therefore needed.

A second instructional implication has to do with the essence of developing reading skills: the more people read, the better they become at it (Cox \& Guthrie, 2001; Mullis et al., 2007; OECD, 2009). In addition to the CS courses, students should engage in reading extensively as part of their academic courses. Although university students in Ghana claim to value their textbooks, they prefer to learn course content from other resources, such as lectures and lecture notes (Owusu-Acheaw \& Larson, 2014; Stoffelsma, 2018). This behavior, combined with limited access to reading resources, limits students' reading development. It is therefore essential that university courses include reading assignments and provide sufficient access to reading materials.

The sample of our study does not differ from samples in similar studies in Ghana (Stoffelsma \& Spooren, 2013) and is therefore representative of science and mathematics university students in Ghana. The finding that $10.3 \%$ of the students reported using English in their home environment is in line with Ghana being considered an ESL country (Ahulu, 1995; Kachru, 1985). The highly heterogeneous population, in terms of age (from 17 to 35 years old), and use of home language (representing 20 different languages) indicates the need for institutions to cater for large discrepancies in terms of age and language skills within their classrooms.

\section{Suggestions for Further Research}

The current study is based on correlational research that could be strengthened by an experimental intervention to investigate a possible causal relationship between language proficiency and academic achievement. As a follow-up of the current study, a content-based language instruction (CBLI) intervention was developed and implemented to improve the reading proficiency of B.Ed. Chemistry students in Ghana. Contentbased language instruction (CBLI) is a systematic collaboration between discipline specific teachers and language specialists to design and deliver disciplinary knowledge through English, see Marsh (2012) for an overview. The study, which yielded promising results, showed that CBLI at tertiary level is possible in a Sub-Saharan African context in a Chemistry course and that both students and lecturers were supportive of the approach (Stoffelsma \& Spooren, 2013; Stoffelsma et al., 2017). Thus far, this approach has mostly been tested at primary or secondary level in Western countries (Fang et al., 2008; Spektor-Levy, Eylon, \& Scherz, 2008).

Finally, the current study was based on text-based print. In view of the rise of technology and online learning, it would be interesting to investigate alternative forms of reading. This is only viable if the computer and internet access level in the institutions increases (see below).

\section{Limitations}

Mediation analysis is based on correlational research that does not automatically establish causality. However, Hayes (2013) argues that "sometimes theory or solid 
argument is the only foundation upon which a causal claim can be built given limitations of our data" (p. 89).

Secondly, the instruments used in this study consisted of only a sample of items from PISA Reading and from PTE Academic and not a complete set. Results should therefore be interpreted as an indication of reading ability of students at the group level, and not as a measure of individual reading ability.

A final limitation is the fact that ICT and online reading were not included in the study. Traditional media continue to play a dominant role in Ghana. Computer access level, ownership and internet access are highly restricted and therefore online reading does not yet play the important role in education that it does in the more affluent Western countries. Three important factors hinder ICT integration in education. Firstly, ICT resources for teaching and learning are inadequate or non-existent. Secondly, the ICT competencies of teachers are very limited, and thirdly, major deficiencies in the curricula exist that do not cater for inclusion of ICT tools in teaching and learning. The fact that the computer-student ratio at the institutions was approximately 1:200 during the time of this study illustrates the ICT challenges (Issifu, 2011).

Acknowledgements The authors would like to express their sincere thanks to the students and academic staff in Ghana for their generous participation in the study as well as to their institution for accommodating the research. A special thanks to Dr. Victor Antwi for his kind assistance during the data collection. We also thank two anonymous reviewers for their comments on an earlier version of this report.

Open Access This article is distributed under the terms of the Creative Commons Attribution 4.0 International License (http://creativecommons.org/licenses/by/4.0/), which permits unrestricted use, distribution, and reproduction in any medium, provided you give appropriate credit to the original author(s) and the source, provide a link to the Creative Commons license, and indicate if changes were made.

\section{References}

Afful, J. B. A. (2007). Academic literacy and communicative skills in the Ghanaian university: A proposal. Nebula, 4, 141-159.

Ahulu, S. (1995). Hybridized English in Ghana. English Today: The International Review of the English Language, 11(4), 31-36. https://doi.org/10.1017/S0266078400008609

Ampiah, J. G., Akyeampong, K., \& Leliveld, M. (2002). Science, Mathematics and ICT (SMICT) Education in sub-Saharan Africa, Ghana Country Paper. Amsterdam, The Netherlands: Center for International Cooperation, VU University.

Akyeampong, K. (2010). 50 Years of educational progress and challenge in Ghana (Research Monograph No. 33). Brighton, England: University of Sussex, Centre for International Education.

Ansaldo, A. I., Marcottea, K., Schererc, L., \& Raboyeaua, G. (2008). Language therapy and bilingual aphasia: Clinical implications of psycholinguistic and neuroimaging research. Journal of Neurolinguistics, 21, 539-557.

Barton, M. L., \& Jordan, D. L. (2001). Teaching reading in science. A supplement to teaching reading in the content areas: If not me, then who? Aurora, CO: McREL.

Barwell, R., Barton, B., \& Setati, M. (2007). Multilingual issues in mathematics education: Introduction. Educational Studies in Mathematics, 64(2), 113-119.

Birch, B. M. (2015). English L2 reading: Getting to the bottom (3rd ed.). New York, NY: Routledge.

Bond, T., \& Fox, C. M. (2015). Applying the Rasch model: Fundamental measurement in the human sciences (3rd ed.). New York, NY: Routledge.

Boughey, C. (2005). Epistemological access to the university: An alternative perspective. South African Journal of Higher Education, 19(3), 638-650. 
Buabeng, I., Acheaw Owusu, K., \& Danso Ntow, F. (2014). TIMSS 2011 science assessment results: A review of Ghana's performance. Journal of Curriculum and Teaching, 3(2), 1-12.

Carnegie Council on Advancing Adolescent Literacy. (2010). Time to act: An agenda for advancing adolescent literacy for college and career success. New York, NY: Carnegie Corporation of New York.

Cooke, E., Hague, S., \& McKay, A. (2016). The Ghana poverty and inequality report: Using the 6th Ghana living standards survey. UNICEF, University of Sussex, Ashesi University College Ghana.

Council of Europe. (2001). Common European Framework of Reference for languages: Learning, teaching, assessment (CEFR). Strasbourg, France: Language Policy Division, Council of Europe.

Cox, K. E., \& Guthrie, J. T. (2001). Motivational and cognitive contributions to students' amount of reading. Contemporary Educational Psychology, 26, 116-131.

De Boer, G. E. (2000). Scientific literacy: Another look at its historical and contemporary meanings and its relationship to science education reform. Research in Science Teaching, 37(3), 582-601.

De Feiter, L. (2006). PRACTICAL project interim inception report. Amsterdam, The Netherlands: Centre for International Cooperation, VU University.

Dowse, C., \& Howie, S. (2013). Promoting academic research writing with South African master's students in the field of education. In T. Plomp \& N. Nieveen (Eds.), Educational design research-Part B: Illustrative cases (pp. 851-879). Enschede, The Netherlands: SLO.

Droop, M., \& Verhoeven, L. (2003). Language proficiency and reading ability in first and second language learners. Reading Research Quarterly, 38(1), 78-103.

Fang, Z. (2006). The language demands of science reading in middle school. International Journal of Science Education, 28(5), 491-520. https://doi.org/10.1080/09500690500339092.

Fang, Z., Lamme, L., Pringle, R., Patrick, J., Sanders, J., Zmach, C., Henkel, M. (2008). Integrating reading into middle school science: What we did, found and learned. International Journal of Science Education, 30(15), 2067-2089. https://doi.org/10.1080/09500690701644266.

Fang, Z., \& Wei, Y. (2010). Improving middle school students' science literacy through reading infusion. The Journal of Educational Research, 103(4), 262-273. https://doi.org/10.1080/00220670903383051.

Grabe, W. (2009). Reading in a second language: Moving from theory to practice. New York, NY: Cambridge University Press.

Hand, B. M., Alvermann, D. E., Gee, J., Guzzetti, B. J., Norris, S. P., Phillips, L. M., . . Yore, L. D. (2003). Guest editorial. Message from the "island group": What is literacy in science literacy? Journal of Research in Science Teaching, 40(7), 607-615.

Hayes, A. F. (2013). Introduction to mediation, moderation, and conditional process analysis: A regressionbased approach. New York, NY: Guilford Press.

Helman, L. A., \& Burns, M. K. (2008). What does oral language have to do with it? Helping young Englishlanguage learners acquire a sight word vocabulary. The Reading Teacher, 62(1), 14-19. https://doi. org/10.1598/RT.62.1.2.

Inglis, M., Kirkwood, T., Downs, C. T., \& Parkinson, J. (2007). Writing their way into science: Gaining access to the discourse of biology. Journal for Language Teaching, 41(1), 82-99.

Issifu, Y. (2011). [ICT resources at the University of Education Winneba (personal communication)].

Kachru, B. B. (1985). Standards, codification and sociolinguistic realism: The English language in the outer circle. In R. Quirk \& H. G. Widdowson (Eds.), English in the world: Teaching and learning the language and literatures (pp. 11-30). Cambridge, England: Cambridge University Press.

Korpershoek, H., Kuyper, H., \& Van der Werf, G. (2015). The relation between students' math and reading ability and their mathematics, physics, and chemistry examination grades in secondary education. International Journal of Science and Mathematics Education, 13, 1013-1037.

Leherr, K. (2009). National Literacy Acceleration Program (NALAP) Baseline Assessment Ghana. Washington, DC: Education Development Center.

Lems, K., \& Miller, L. D. (2017). Building literacy with English language learners, insights from linguistics (2nd ed.). New York, NY: The Guilford Press.

Locke, D. (1992). Science as writing. New Haven, CT: Yale University Press.

Lyengar, S. (2007). To read or not to read a question of national consequence (Research report No. 47). Washington, DC: Office of Research \& Analysis, National Endowment for the Arts.

Marsh, D. (2012). Content and language integrated learning (CLIL): A development trajectory. Córdoba, Spain: Servicio de Publicaciones de la Universidad.

Martin, M. O., Foy, P., \& Stanco, G. M. (2012). TIMSS 2011 International results in science. Chestnut Hill, MA: International Association for the Evaluation of Educational Achievement (IEA).

Martin, M. O., Mullis, I. V. S., \& Chrostowski, S. J. (2003). TIMMS 2003 technical report. Boston, MA: TIMSS \& PIRLS International Study Center. 
Mereku, D. K., \& Anumel, C. R. (2011). Ghana's achievement in mathematics in TIMSS 2007. Mathematics Connection, 10, 83-99.

Ministry of Education Ghana. (2008). 2007 National education assessment report. Accra, Ghana: Author.

Ministry of Education Ghana. (2010). Report on the 2009 administration of national education assessment in Primary 3 and Primary 6, English and mathematics. Accra, Ghana: Author.

Ministry of Education Ghana. (2016). National training of trainers workshop for teachers of mathematics ends in Accra. Retrieved 16-09-2016, from http://www.ghana.gov.gh/index.php/mediacenter/news/1856-national-training-of-trainers-workshop-for-teachers-of-mathematics-ends-in-accra

Mol, S. E., \& Bus, A. G. (2011). To read or not to read: A meta-analysis of print exposure from infancy to early adulthood. Psychological Bulletin, 137(2), 267-296. https://doi.org/10.1037/a0021890.

Moskovich, J. (2007). Using two languages when learning mathematics. Educational Studies in Mathematics, 64(2), 121-144.

Mullis, I. V. S., Martin, M. O., Gonzalez, E. J., \& Chrostowski, S. J. (2004). TIMMS 2003 International Science Report. Findings From IEA's Trends in International Mathematics and Science Study at the Fourth and Eighth Grades. Chestnut Hill, MA: International Association for the Evaluation of Educational Achievement (IEA).

Mullis, I. V. S., Martin, M. O., Kennedy, A. M., \& Foy, P. (2007). PIRLS 2006 international report; IEA's progress in international reading literacy study in primary schools in 40 countries. Boston, MA: International Association for the Evaluation of Educational Achievement (IEA).

Ní Ríordáin, M., \& O'Donoghue, J. (2009). The relationship between performance on mathematical word problems and language proficiency for students learning through the medium of Irish. Educational Studies in Mathematics, 71, 43-64.

Norris, S. P., \& Phillips, L. M. (2003). How literacy in its fundamental sense is central to scientific literacy. Science Education, 87, 224-240.

Odamtten, H., Denkabe, A., \& Tsikata, I. E. (2015). The problem of English language skills at the university level: A case study of first-year law and administration students at the University of Ghana. In G. S. K. Adika \& C. C. Asante (Eds.), Multilingualism, language in education, and academic literacy: Applied linguistics research in the language Centre (pp. 56-82). Accra, Ghana: University of Ghana Readers - Sub Saharan Publishers.

Organisation for Economic Co-operation and Development. (2002). Programme for international student assessment, sample tasks from the PISA 2000 assessment of reading, mathematical and scientific literacy (p. 117). Paris, France: Author.

Organisation for Economic Co-operation and Development. (2006). PISA released items - reading. Paris, France: Author.

Organisation for Economic Co-operation and Development. (2009). PISA 2009 assessment framework, key competencies in reading, mathematics and science. Paris, France: Author.

Organisation for Economic Co-operation and Development. (2013). PISA 2015 draft science framework. Paris, France: Author.

Owusu-Acheaw, M., \& Larson, A. G. (2014). Reading habits among students and its effect on academic performance: A study of students of Koforidua polytechnic. Library Philosophy and Practice, Paper, $1130,1-22$.

Palinscar, A. (2013). The next generation science standards and the common core state standards: Proposing a happy marriage. Science and Children, 51(1), 10-15.

Paran, A., \& Williams, E. (2007). Editorial: Reading and literacy in developing countries. Journal of Research in Reading, 30(1), 1-6.

Pretorius, E. J. (2000). Reading and the UNISA student: Is academic performance related to reading ability? Progressio, 22(2), 35-48.

Pretorius, E. J. (2002). Reading ability and academic performance in South Africa: Are we fiddling while Rome is burning? Language Matters, 33(1), 179-208.

Pretorius, E. J. (2005). What do students do when they read to learn? Lessons from five case studies. South African Journal of Higher Education, 19(4), 790-812.

Pretorius, E. J. (2006). The comprehension of logical relations in expository texts by students who study through the medium of ESL. System, 34, 432-450.

Pretorius, E. J., \& Bohlmann, C. A. (2003). A reading intervention programme for mathematics students. South African Journal of Higher Education, 17(2), 226-236.

Pretorius, E. J., \& Mampuru, D. M. (2007). Playing football without a ball: Language, reading and academic performance in a high-poverty school. Journal of Research in Reading, 30(1), 38-58. 
Prins, E. D., \& Ulijn, J. M. (1998). Linguistic and cultural factors in the readability of mathematics texts: The Whorfian hypothesis revisited with evidence from the south African context. Journal of Research in Reading, 21(2), 139-159.

Rhodes, H., \& Feder, M. A. (2014). Literacy for science. Exploring the intersection of the next generation science standards and common core for ELA standards. In B. O. S. Education (Ed.), A workshop summary (p. 124). Washington, DC: National Research Council.

Spektor-Levy, O., Eylon, B. S., \& Scherz, Z. (2008). Teaching communication skills in science: Tracing teacher change. Teaching and Teacher Education, 24, 462-477.

Stæhr, L. S. (2008). Vocabulary size and the skills of listening, reading and writing. Language Learning Journal, 36(2), 139-152. https://doi.org/10.1080/09571730.

Stanovich, K. (2000). Progress in understanding reading: Scientific foundations and new frontiers. New York, NY: Guilford Press.

Stoffelsma, L. (2018). Short-term gains, long-term losses? A diary study on literacy practices in Ghana. Journal of Research in Reading. https://doi-org.ru.idm.oclc.org/10.1111/1467-9817.12136.

Stoffelsma, L., \& Spooren, W. (2013). Reading and knowledge transfer in Ghana: The behaviour, attitudes and self-concepts of first-year students in Bachelor of Education programmes. Educational Psychology, 33(6), 690-718. doi: 10.1080/01443410.2013.785047.

Stoffelsma, L., \& De Jong, J. H. A. L. (2015). The English reading proficiency of future teachers in Ghana. Nordic Journal of African Studies, 24(2), 94-117.

Stoffelsma, L., \& Spooren, W. (2017). Improving the academic reading proficiency of university students in Ghana: An educational design research approach. Language Matters, 48(1), 48-70. https://oi. org/10.1080/10228195.2017.1296017

Stoffelsma, L., Mwinlaaru, I. N., Otchere, G., Owusu-Ansah, A. L., \& Adjei, J. A. (2017). Curriculum design in practice: Improving the academic reading proficiency of university students in Ghana. Ibérica, 33, 97124.

Van Wyk, A. L., \& Greyling, W. J. (2008). Developing reading in a first-year academic literacy course. Stellenbosch Papers in Linguistics, 38, 205-219.

Vilenius-Tuohimaa, P. M., Aunola, K., \& Nurmi, J. (2008). The association between mathematical word problems and reading comprehension. Educational Psychology, 28, 426-443.

Walker, C. M., Zhang, B., \& Surber, J. (2008). Using a multidimensional differential item functioning framework to determine if reading ability affects student performance in mathematics. Applied Measurement in Education, 21, 162-181.

World Bank. (2011). Global Economic Prospects, maintaining progress amid turmoil (Vol. 3). Washington, DC: World Bank. 